УДК [631.44.06:550.424](234.86)

\title{
РАСПРЕДЕЛЕНИЕ И МИГРАЦИЯ ХИМИЧЕСКИХ ЭЛЕМЕНТОВ В ПОЧВАХ ХРЕБТА МАГНИТНОГО (ГПЗ «КАРАДАГСКИЙ»)
}

Дрыгваль П. В. ${ }^{1}$ Дрыгваль А. В. ${ }^{1,2}$, Лебедев Я. О. ${ }^{3}$, Горбунов Р. В. ${ }^{2}$, Станис Е. В. ${ }^{1}$, Фам Кам Ньунг

${ }^{1}$ Российский университет дружбы народов, г. Москва, Российская Федерация,

${ }^{2}$ ФГБУН ФИЦ «Институт биологии южных морей имени А. О. Ковалевского РАН»,

2. Севастополь, Российская Федерация,

${ }^{3}$ Московское представительство ФГБУН ФИЦ «Институт биологии южных морей имени

А. О. Ковалевского РАН», г. Москва, Российская Федерация,

e-mail:any-poly@mail.ru

В статье затронут вопрос распространения и миграции некоторых химических элементов в пределах почвенной катены, заложенной на территории горного массива Карадаг (хребет Магнитный). Катена представлена тремя точками (почвенными разрезами), заложенными на вершине хребта Магнитного, а также на его склонах северо-западной и юго-восточной экспозиций. Разрезы заложены в автоморфных и трансаккумулятивных условиях формирования почв. Даны подробные описания почвенных разрезов, а также проведён химический анализ проб почвенных горизонтов. В пробах почв определены: актуальная кислотность, количество гумуса, содержание некоторых микро- и макроэлементов в валовой и подвижной формах. Рассмотрен характер миграции некоторых химических элементов как в пределах разрезов, так и в пределах заложенной катены в целом. Отмечено, что исследованные химические элементы из почв, развивающихся в автоморфных ландшафтных условиях, на водораздельном хребте Магнитном (точка 2) мигрируют с последующей аккумуляцией в соподчинённые трансаккумулятивные ландшафты склонов (точки 1 и 3), занятых лесной растительностью. Кроме того, концентрация всех исследованных элементов в органогенных горизонтах почв трансаккумулятивных ландшафтных условий склонов выше, чем в почвах автоморфных условий плакорной поверхности водораздела.

Ключевые слова: миграция элементов, почвы заповедника, геохимическое сопряжение, почвенная катена, Карадагский заповедник.

\section{Введение}

Комплексное геохимическое исследование почв Карадагского заповедника является значимой основой для понимания функционирования природных экосистем, так как почвы являются узловым звеном экологических систем, которое влияет на их биоразнообразие и возможность существования биогеоценозов в целом. Почвы регулируют процессы миграции веществ в ландшафтах, являясь при этом аккумулирующей буферной зоной. Изучение характера распределения и миграции химических элементов в почве даёт понимание процессов миграции вещества, происходящих в ландшафте. Изучение почв в заповедных, малонарушенных зонах является важным направлением, так как позволяет осуществить решение большого диапазона задач. Именно такие территории являются эталонными участками для сравнения состояния природных систем в похожих условиях.

Изучению почв горных территорий посвящено довольно много работ, связанных с комплексными исследованиями как самих почв, так и факторов, влияющих на их формирование и развитие [Иванов, 1958; Кочкин, 1967]. Следует выделить отдельно

\footnotetext{
*Работа выполнена по теме государственного задания ФИЦ ИнБЮМ, регистрационный номер 121040100327-3.
} 
работы, посвящённые геохимическим особенностям почвенного покрова Крымского полуострова [Алексашкин, Хижняк, Горбунов, 2007; Ежов и др., 2014; Опанасенко, 2014]. В частности, геохимическим особенностям поверхностных отложений и закономерностям распределения микроэлементов в почвах, в том числе заповедных зон, были посвящены работы [Жовинский, Кураева, 2002; Локтионова и др., 2014]. Изучением ландшафтногеохимических особенностей Крымского полуострова занималась группа авторов с работами [Важкі метали ..., 2005; Михаленок, 1989].

Цель настоящего исследования - выявление основных закономерностей распределения и миграции некоторых химических элементов в почвах хребта Магнитного в Карадагском природном заповеднике.

\section{Результаты и обсуждение}

Территория исследования находится в пределах горного массива Карадаг. Он сложен разнообразными вулканическими и осадочными горными породами. Территория занята лесными сообществами, редколесьем, степным травостоем в комплексе с каменистыми обнажениями горных пород. Литолого-геоморфологическое и экологическое разнообразие современных условий и процессов почвообразования на Карадаге формируют высокую пространственную дифференциацию типов почв заповедника.

В целях изучения характера распространения и миграции химических элементов в почве Карадагского заповедника была заложена почвенная катена в пределах хребта Магнитного. Она представлена тремя точками (почвенными разрезами), заложенными на вершине хребта (точка 2), а также на склонах северо-западной и юго-восточной экспозиций (точки 1 и 3 соответственно). Следует отметить, что расположение точек профиля 1 и 3 на склонах северо-западной и юго-восточной экспозиций обусловливает различные инсоляционные и импульверизационноциркуляционные процессы, влияющие на характер распространения и миграции химических элементов в почве.

Почвенная катена составляет два геохимических сопряжения от вершины хребта Магнитного до точек на склонах. Согласно геологической карте [Петрографическая карта ... , 1933] хребет Магнитный в зоне заложения почвенной катены сложен туфами и туфобрекчиями, потоками спилитов, кератоспилитов, андезитов и андезито-базальтов верхнебайоского возраста.

Точки почвенной катены были выбраны с учётом различных ландшафтно-геохимических условий — автоморфных и трансаккумулятивных условий почвообразования. Почвенная катена изображена на рис. 1.

Пробы почвы отбирались из каждого почвенного горизонта для дальнейших лабораторных исследований. Были определены следующие показатели: актуальная кислотность почвы, количество гумуса, содержание в почвах некоторых микро- и макроэлементов в валовой и подвижной формах, гранулометрический состав почв.

Актуальную кислотность почвы определяли по показателю $\mathrm{pH}$ её водной вытяжки. Количественное определение гумуса осуществлялось по методу Тюрина. Валовые и подвижные формы элементов в почве определяли с помощью масс-спектрометра с индуктивно связанной плазмой PlasmaQuant MS Elite на базе научно-образовательного центра коллективного пользования «Спектрометрия и хроматография» ФИЦ ИнБЮМ.

Почвенный разрез № 1 (точка 1 почвенной катены) представлен дерново-бескарбонатной слабоскелетной среднесуглинистой почвой, сложенной на делювии верхнеюрских туфов и туфобрекчий. В разрезе выделены горизонты: А0 — Ad - A - BC. Он заложен на склоне северо-западной экспозиции хребта Магнитного. Поверхность участка наклонная, кочковатая. Уклон поверхности составляет $15^{\circ}, 319$ м н. у. м. Разрез заложен под пушистодубово-ясеневым лесом. Территория соответствует трансаккумулятивным условиям формирования почвы (рис. 2А). 


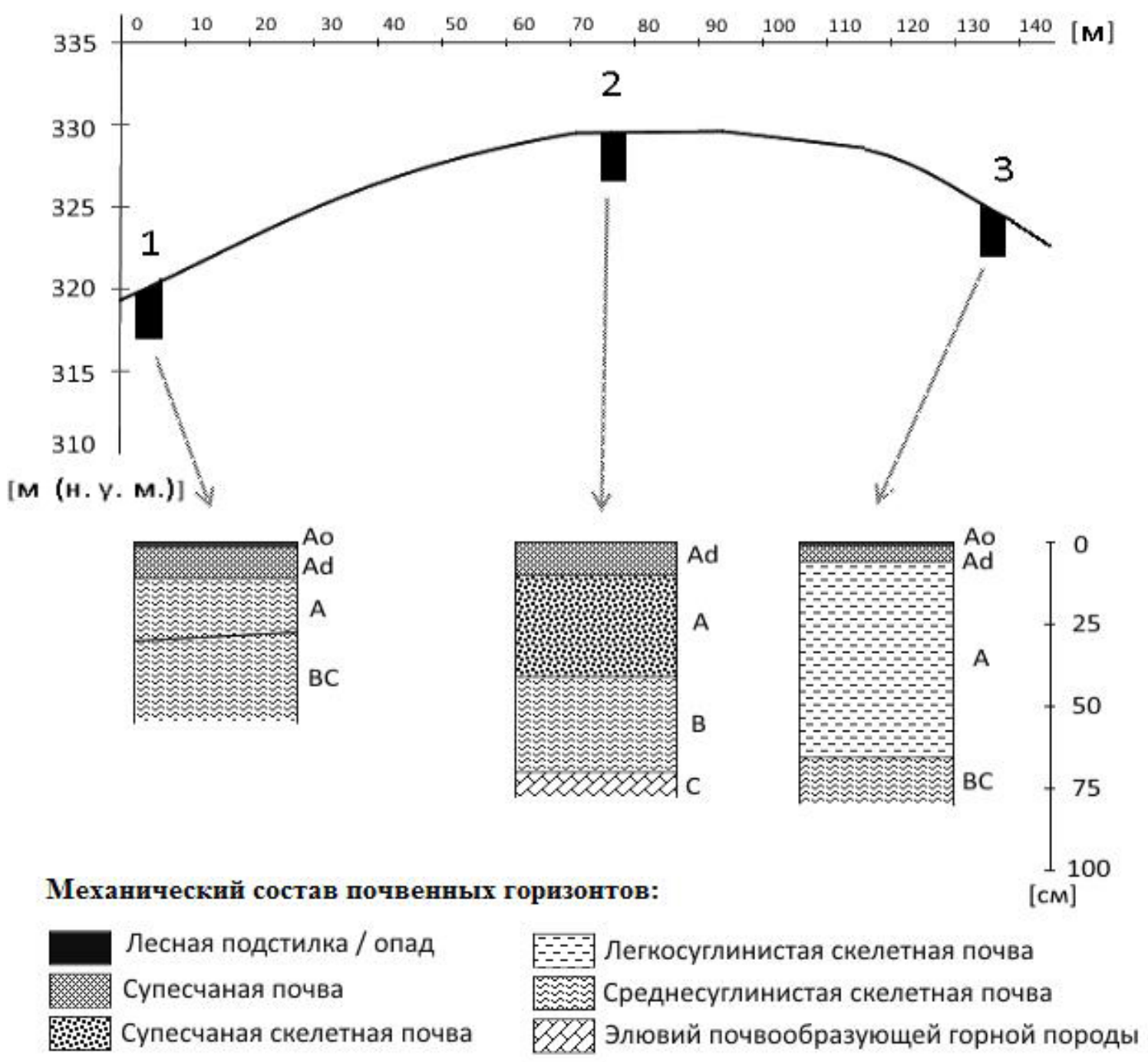

Рис. 1. Почвенная катена на хребте Магнитном

Горизонт А0. Горизонт представлен лесной подстилкой, состоящей из сухой опавшей листвы дуба пушистого (Quercus pubescens).

Горизонт Ad. Глубина залегания - 1-12 см, мощность - 11 см, почва чёрная (7,5YR 2,5/1), сухая, супесчаная, мелкокомковато-пылеватая, рыхлая; новообразований нет; включений нет; живая фаза представлена корнями растений; характер перехода к следующему горизонту ясный по плотности; форма нижней границы ровная.

Горизонт А. Глубина залегания - 12-25/30 см, мощность - 13-18 см, почва тёмнокоричневая (7,5YR 3/2), свежая, представлена средним суглинком, пылевато-мелкокомковатая, плотная; новообразований нет; включения представлены мелким делювием в виде дресвы (с ржавыми, светло-оранжевыми пятнами на гранях включений и до 2 см в диаметре); живой фазы нет; характер перехода к следующему горизонту ясный по плотности; форма нижней границы слабонаклонная.

Горизонт ВС. Видимая глубина залегания - 25/30-55 см, видимая мощность - 25-30 см, почва тёмно-серовато-коричневая (10YR 4/2), свежая, средний суглинок, мелко- и среднекомковатая, очень плотная; новообразований нет; включения представлены щебнем, дресвой, валунами делювия (с ржавыми, светло-оранжевыми пятнами на гранях включений); живой фазы нет. 


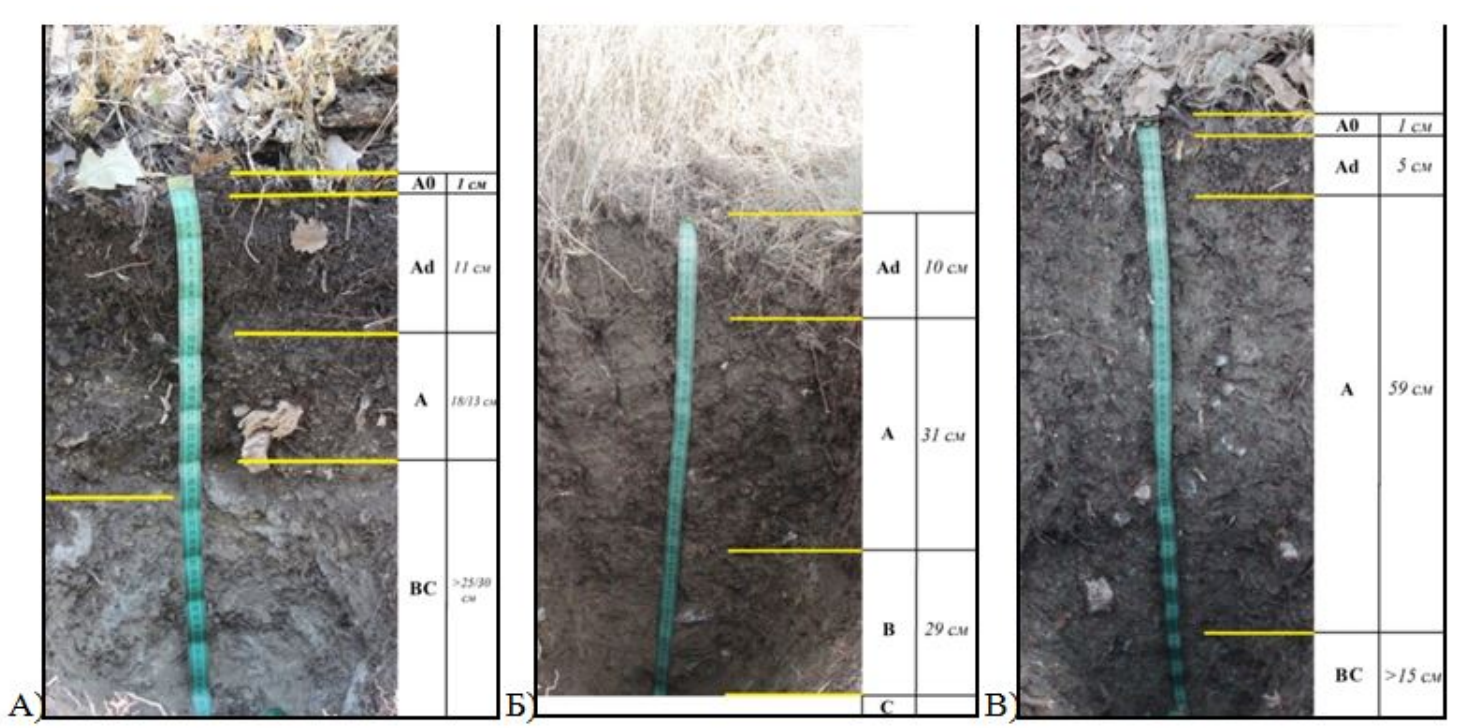

Рис. 2. А 一 почвенный разрез № 1, Б — почвенный разрез № 2, В — почвенный разрез № 3

Таблица 1

Содержание химических элементов в почвах катены в валовой и подвижной (выделено цветом) формах, мг/кг

\begin{tabular}{|c|c|c|c|c|c|c|c|c|c|}
\hline № разреза & \multicolumn{3}{|c|}{$\mathbf{1}$} & \multicolumn{3}{|c|}{$\mathbf{2}$} & \multicolumn{3}{|c|}{$\mathbf{3}$} \\
\hline Горизонт & $\mathbf{A d}$ & $\mathbf{A}$ & $\mathbf{B C}$ & $\mathbf{A d}$ & $\mathbf{A}$ & $\mathbf{B}$ & $\mathbf{A d}$ & $\mathbf{A}$ & $\mathbf{B C}$ \\
\hline \multirow{2}{*}{$\mathbf{K}$} & 3061,8 & 1101,0 & 723,5 & 1147,2 & 1237,7 & 521,1 & 2789,4 & 1449,1 & 435,0 \\
& 1525,6 & 348,2 & 228,2 & 960,4 & 1058,8 & 846,6 & 941,1 & 462,3 & 170,0 \\
\hline \multirow{2}{*}{$\mathbf{M g}$} & 3052,4 & 3130,0 & 4958,8 & 1439,2 & 2073,4 & 2740,9 & 3650,5 & 3412,6 & 2428.9 \\
& 805,7 & 955,0 & 878,8 & 818,1 & 1372,8 & 1783,0 & 853,1 & 1059,8 & 1156,0 \\
\hline \multirow{2}{*}{$\mathbf{A l}$} & 29547,2 & 11415,1 & 11489,7 & 8928,2 & 7645,8 & 15212,6 & 11341,5 & 17434,0 & 9763,7 \\
& 6,7 & 19,4 & 23,0 & 25,5 & 36,7 & 57,2 & 11,0 & 18,6 & 19,2 \\
\hline \multirow{2}{*}{$\mathbf{F e}$} & 6395,9 & 6320,9 & 7479,3 & 3724,2 & 5057,5 & 5791,2 & 7019,3 & 5909,1 & 3158,6 \\
& 19,6 & 18,1 & 14,0 & 11,2 & 22,0 & 27,2 & 14,2 & 16,2 & 19,3 \\
\hline \multirow{2}{*}{$\mathbf{M n}$} & 605,4 & 481,7 & 505,9 & 357,8 & 452,8 & 615,4 & 492,6 & 352,8 & 204,5 \\
& 43,7 & 50,2 & 39,6 & 54,9 & 57,1 & 34,2 & 29,9 & 42,6 & 34,6 \\
\hline \multirow{2}{*}{$\mathbf{S r}$} & 60,2 & 41,8 & 43,1 & 17,2 & 27,9 & 37,8 & 60,7 & 46,9 & 51,5 \\
& 30,8 & 21,8 & 19,5 & 18,2 & 16,6 & 15,3 & 22,1 & 19,0 & 20,6 \\
\hline \multirow{2}{*}{$\mathbf{Z n}$} & 56,7 & 35,5 & 38,6 & 33,6 & 36,8 & 42,5 & 42,5 & 37,6 & 22,1 \\
& 2,0 & 0,6 & 1,1 & 0,8 & 0,9 & 0,4 & 1,8 & 1,0 & 0,4 \\
\hline \multirow{2}{*}{$\mathbf{C u}$} & 12,0 & 5,8 & 6,5 & 5,2 & 3,6 & 4,1 & 9,8 & 11,0 & 2,3 \\
& 0,2 & 0,2 & 0,3 & 0,1 & 0,1 & 0,1 & 0,3 & 0,2 & 0,1 \\
\hline \multirow{2}{*}{$\mathbf{P b}$} & 12,6 & 6,7 & 7,4 & 4,9 & 5,4 & 5,7 & 8,8 & 6,3 & 4,0 \\
& 0,6 & 0,2 & 0,3 & 0,2 & 0,2 & 0,1 & 0,3 & 0,2 & 0,3 \\
\hline
\end{tabular}

Почвенный разрез № 2 (точка 2 почвенной катены) представлен дерново-бескарбонатной супесчано-среднесуглинистой слабоскелетной почвой, сложенной на элювии верхнеюрских туфов и туфобрекчий. В разрезе выделены горизонты: Ad - A - B - C. Он заложен на вершине хребта Магнитного, на слабонаклонной, субгоризонтальной поверхности с уклоном 5, 329 м н. у. м. Территория соответствует автоморфным условиям формирования почвы (рис. 2Б). 
Горизонт Ad. Глубина залегания - 0-10 см, мощность - 10 см, почва тёмно-сероватокоричневая (2,5Y 3/2), сухая, супесчаная, мелкокомковато-пылеватая, рыхлая; новообразований нет; включений нет; живая фаза представлена корнями растений; характер перехода к следующему горизонту ясный по включениям и плотности; форма нижней границы ровная.

Горизонт А. Глубина залегания - 10-41 см, мощность - 31 см, почва тёмно-коричневая (10YR 2/2), сухая, супесчаная, мелко- и среднекомковатая, очень плотная; новообразований нет; включения представлены мелким щебнем и дресвой элювия (очень мало); живая фаза представляет собой корни растений; характер перехода к следующему горизонту явный по цвету; форма нижней границы слабоволнистая.

Горизонт В. Глубина залегания - 41-70 см, мощность - 29 см, почва оливково-коричневая (2,5Y 4/3), сухая, представлена средним суглинком, пылевато-мелкокомковатая, очень плотная; новообразования единично представлены маленькими чёрными (угольными) примазками; включения - мелкий щебень и дресва элювия (больше, чем в горизонте А), видны белые примазки от включений элювия; живой фазы нет; характер перехода к следующему горизонту определяется по плотности.

Горизонт С. Видимая глубина залегания - 70 см и ниже.

Почвенный разрез № 3 (точка 3 почвенной катены) представлен дерново-бескарбонатной супесчано-суглинистой скелетной почвой, сложенной на делювии верхнеюрских туфов и туфобрекчий. В разрезе выделены горизонты: A0 - Ad - A - BC. Он заложен на склоне юго-восточной экспозиции хребта Магнитного. Поверхность участка наклонная, уклон $15^{\circ}, 324$ м н. у. м. Разрез заложен под пушистодубовым лесом. Точка представляет собой трансаккумулятивные условия формирования почвы (рис. 2В).

Горизонт А0. Глубина залегания - 0-1 см, опад, представленный сухими листьями дуба пушистого (Quercus pubescens).

Горизонт Ad. Глубина залегания - 1-6 см, мощность - 5 см, почва чёрная (7,5YR 2,5/1), сухая, супесчаная, мелко- и среднекомковато-пылеватая, уплотнённая; новообразований нет; включений нет; живая фаза представлена корнями растений; характер перехода к следующему горизонту ясный по включениям, цвету и плотности; форма нижней границы ровная.

Горизонт А. Глубина залегания - 6-65 см, мощность - 59 см, почва тёмно-коричневая (10YR 2/2), свежая, представлена легким суглинком, крупно- и среднеореховатая, плотная; новообразования представлены чёрной (угольной) примазкой 2 см в диаметре, а включения мелкой дресвой и щебнем; живая фаза представлена корнями растений (дуба); характер перехода к следующему горизонту плавный по цвету; форма нижней границы ровная.

Горизонт ВС. Видимая глубина залегания - 65-80 см, мощность - 15 см, почва тёмнокоричневая (10YR 2/2), сухая, представлена средним суглинком, крупно- и среднеореховатая, плотная; новообразований нет; включения представлены крупным щебнем и мелкой дресвой; живой фазы нет.

Рассмотрим геохимические особенности миграции элементов в пределах рассматриваемойтерритории, начиная с водораздела.

Дерново-бескарбонатная супесчано-среднесуглинистая слабоскелетная почва (сложенная на элювии верхнеюрских туфов и туфобрекчий) (точка 2) формируется на водораздельном пространстве в автоморфных условиях под степным злаковым сообществом. Данное обстоятельство обусловливает активный поверхностный сток - снос вещества вниз по склонам. Также эти условия способствуют накапливанию влаги от атмосферных осадков в почве и её депонированию в минеральных горизонтах в комплексе с активными процессами испарения влаги в поверхностных слоях почвы вследствие инсоляционной активности на водораздельной поверхности. 
ДРЫГВАЛЬ П. В., ДРЫГВАЛЬ А. В., ЛЕБЕДЕВ Я. О., ГОРБУНОВ Р. В., СТАНИС Е. В., ФАМ КАМ НЬУНГ

Таблица 2

Значения рН, содержания гумуса и гранулометрического состава почв катены

\begin{tabular}{|c|c|c|c|c|c|c|c|}
\hline \multirow{2}{*}{ № разреза } & \multirow{2}{*}{ Горизонт } & \multirow{2}{*}{$\mathbf{p H}$} & \multirow{2}{*}{ Гумус, \% } & \multicolumn{4}{|c|}{ Гранулометрический состав, \% } \\
\cline { 5 - 8 } & & & & $<\mathbf{0 , 1}$ мм & $\mathbf{0 , 1 - 0 , 2 5}$ мм & $\mathbf{0 , 2 5 - 0 , 5}$ мм & $\mathbf{0 , 5 - 1}$ мм \\
\hline \multirow{3}{*}{1} & Ad & 7,2 & 15,5 & 7,1 & 26,2 & 40,5 & 26,2 \\
& $\mathbf{A}$ & 7,0 & 3,1 & 11,9 & 31,0 & 40,5 & 16,6 \\
& BC & 6,0 & 5,6 & 9,1 & 15,9 & 25,0 & 50,0 \\
\hline \multirow{3}{*}{2} & Ad & 6,7 & 12,4 & 15,2 & 36,9 & 37,0 & 10,9 \\
& A & 7,3 & 6,2 & 8,9 & 28,9 & 40,0 & 22,2 \\
& B & 7,4 & 4,7 & 14,3 & 23,8 & 26,2 & 35,7 \\
\hline \multirow{3}{*}{3} & Ad & 7,0 & 9,5 & 9,3 & 23,2 & 34,9 & 32,6 \\
& A & 7,0 & 6,9 & 25,6 & 23,3 & 30,2 & 20,9 \\
& BC & 7,3 & 3,6 & 15,6 & 26,6 & 28,9 & 28,9 \\
\hline
\end{tabular}
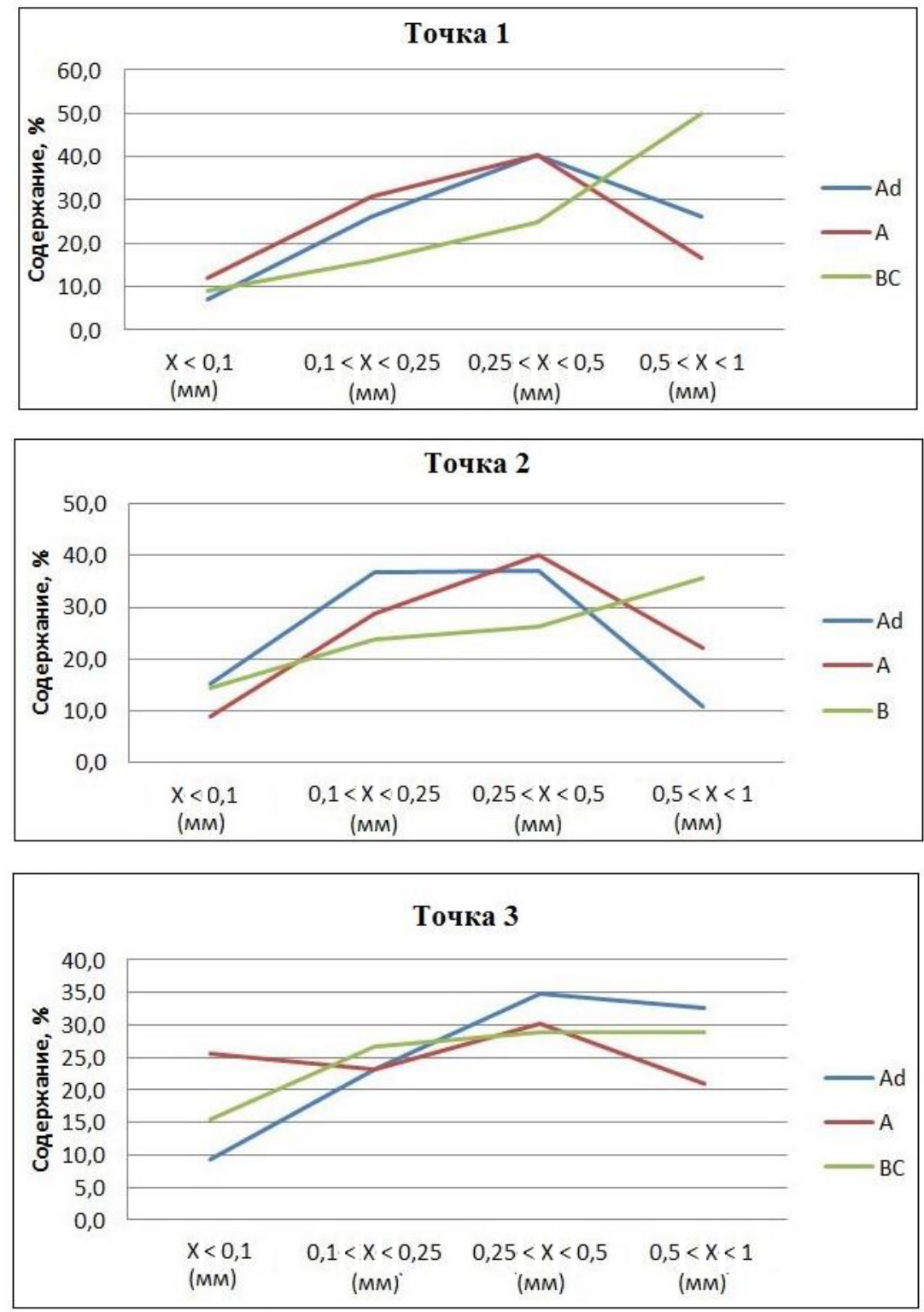

Рис. 3. Гранулометрический состав почв катены на хребте Магнитном 
Гранулометрически в горизонте В (точка 2) преобладает крупный песок, с глубиной количество этой фракции увеличивается (с 10,9 до 35,7 \%). Уменьшение количества крупного песка в верхнем горизонте почвенного разреза (Ad) объясняется активным выносом обломков горных пород и материала грунта и его накапливанием на склонах северо-западной и юго-восточной экспозиций. Поверхностный сток со склона приводит к переносу крупного песка (0,5-1 мм) с горизонтальной поверхности (точка 2) на склоны (точки 1 и 3), что показывают характеристики гранулометрического состава почв (увеличение содержания данной фракции в верхних горизонтах в 2,5 и 3 раза соответственно). Менее активный смыв почвенного материала происходит в сторону склона северо-западной экспозиции хребта Магнитного (точка 1), что объясняется более слабым промывным режимом данного участка.

Отмечается миграция ряда элементов ( $\mathrm{Mg}, \mathrm{Fe}, \mathrm{Mn}, \mathrm{Sr}, \mathrm{Zn}, \mathrm{Pb}$ ) вниз по почвенному разрезу № 2 - от органогенных горизонтов к минеральным. Так, для Mn отмечено постепенное накапливание валовых форм в горизонте В $(615,4$ мг/кг) с уменьшением содержания подвижных форм - от 54,9 мг/кг в горизонте Ad до 34,2 мг/кг в горизонте В. Аналогичное распределение отмечено для $\mathrm{Sr}, \mathrm{Zn}, \mathrm{Pb}$. Для $\mathrm{Mg}$ и $\mathrm{Fe}$ характерно постепенное накапливание валовых (от 1439,2 до 2740,9 мг/кг для $\mathrm{Mg}$; от 3724,2 до 5791,2 мг/кг для $\mathrm{Fe}$ ) и подвижных форм (от 818,1 до 1783,0 мг/кг для $\mathrm{Mg}$; от 11,2 до 27,2 мг/кг для $\mathrm{Fe}$ ) от горизонта Аd к горизонту В, что может являться следствием их содержания в составе почвообразующих горных пород, а также такое накапливание может быть связано с особенностями гранулометрического состава (фракция < 0,1 мм увеличивается до 14,3 \% вниз по почвенному разрезу к горизонту В). Кроме того, $\mathrm{Mg}$, являясь одним из наиболее распространённых талассофильных элементов [Алексеенко, Бузмаков, Панин, 2013], может поступать в гумусовый горизонт с морскими аэрозолями.

B отличие от описанных выше элементов Al имеет несколько иной характер распространения в почвенном разрезе. Al как амфотерный металл активно переходит в подвижную форму в щелочной среде при наличии достаточного увлажнения. В данных условиях наблюдается закономерное постепенное увеличение содержания подвижных форм Al к минеральному горизонту В до 57,2 мг/кг на фоне резкого увеличения концентрации содержания валовых форм в этом горизонте до 15212,6 мг/кг и формирования элювиального горизонта А с уменьшением содержания Al до 7645,8 мг/кг, что находит своё объяснение в изменении гранулометрического состава почвы в этом горизонте - уменьшении содержания фракции частиц $<0,1$ мм до 8,9 \%, так как кислород-гидроксиаллюминиевые и кремнекислородные соединения входят в состав глинистых минералов.

Для $\mathrm{Cu}$ в целом характерна невысокая миграционная активность. Вследствие высокого содержания гумуса $(12,4$ \%) в горизонте Ad и преобладания фракции < 0,1 мм $(15,2$ \%), $\mathrm{Cu}$ может образовывать слаборастворимые соединения, как, например, карбонат-дигидроксид меди $\left((\mathrm{CuOH})_{2} \mathrm{CO}_{3}\right)$ при реакции с диоксидом углерода $\left(\mathrm{CO}_{2}\right)$. Объёмы поступающих растворов органических кислот, вероятно, недостаточны для активного закономерного выноса Сu из гумусового к минеральным горизонтам, в результате чего Сu частично концентрируется в гумусовом горизонте в валовых формах.

К (калий), вследствие его активного поглощения растениями, особенно злаками, имеющими неглубокое распространение корневой системы, имеет незначительное снижение содержания как подвижной, так и валовой форм в горизонте Ad (до 10 см глубиной) по сравнению с нижележащим горизонтом А (от 10 см и глубже). Высокие показатели миграции К вниз по почвенному разрезу могут быть связаны с его высокой миграционной активностью, постоянным привносом К с морскими аэрозолями (а также с поверхностным стоком с ливневыми осадками), вследствие чего он активно выносится в нижележащие горизонты и далее - в геохимически соподчинённые ландшафты. 
На склоне северо-западной экспозиции в трансаккумулятивных условиях формируется дерново-бескарбонатная слабоскелетная среднесуглинистая почва (сложенная на элювии верхнеюрских туфов и туфобрекчий) и развивается под пушистодубово-ясеневым лесом, произрастающим на наклонной поверхности (15²) северо-западной экспозиции (точка 1$)$.

В почвенном разрезе точки 1 прослеживается схожее распределение валовых форм элементов $\mathrm{Al}, \mathrm{Fe}, \mathrm{Mn}, \mathrm{Sr}, \mathrm{Zn}, \mathrm{Cu}, \mathrm{Pb}$ в почвенных горизонтах, аналогично точке 2. Данные элементы содержатся в наименьшем количестве в горизонте А, залегающем на глубине 12-25/30 см и мощностью от 13 до 18 см. Аккумуляция элементов в валовой форме $\mathrm{Al}, \mathrm{Mn}, \mathrm{Sr}$, $\mathrm{Zn}, \mathrm{Cu}$ и $\mathrm{Pb}$ происходит в органогенном горизонте, a $\mathrm{Fe}$ - в минеральном горизонте. Накапливание этих элементов в верхних и частично в нижних горизонтах почвенного разреза довольно хорошо совпадает с распределением содержания гумуса в почвенном разрезе. Наибольшее содержание гумуса в горизонте A - 15,5 \%, затем, ниже по почвенному разрезу, его содержание резко снижается до 3,1 \% и в минеральном горизонте ВС вновь незначительно увеличивается до 5,6 \%. Таким образом, необходимо отметить, что у элементов $\mathrm{Al}, \mathrm{Mn}, \mathrm{Sr}, \mathrm{Zn}, \mathrm{Cu}$ и $\mathrm{Pb}$ прослеживается схожая тенденция накапливания валовых форм в почвенном разрезе.

K характеризуется накапливанием валовой и подвижной форм элемента в верхнем органическом горизонте (до 3061,8 мг/кг) в связи с его активным биологическим поглощением растениями, имеющимися на поверхности почвенного покрова. В минеральном горизонте происходит плавное снижение содержания К до 723,5 мг/кг.

Обратное распределение по почвенному разрезу имеет $\mathrm{Mg}$. Накапливание в валовой форме происходит закономерно вниз по почвенному разрезу (от 3052,4 до 4958,8 мг/кг), с максимумом в минеральном горизонте ВС. Миграционная активность $\mathrm{Mg}$ в пределах почвенного разреза сравнима с поведением $\mathrm{Mn}$. Для $\mathrm{Mg}$ и $\mathrm{Mn}$ отмечено увеличение содержания подвижных форм в горизонте А (до 955 и 50,2 мг/кг соответственно), обусловленное наличием механического барьера в нижележащем горизонте ВС (увеличение глинистой фракции до 50 \%).

Особый характер распределения отмечен для $\mathrm{Zn}$ и $\mathrm{Pb}$. Как валовые, так и подвижные формы этих элементов имеют максимальные значения концентрации в горизонте $\operatorname{Ad}(56,7$ и 2 мг/кг; 12,6 и 0,6 мг/кг соответственно), минимальные значения концентрации отмечены в горизонте А $(35,5$ и 0,6 мг/кг; 6,7 и 0,2 мг/кг соответственно) с постепенным увеличением к иллювиальному горизонту ВС (38,6 и 1,1 мг/кг; 7,4 и 0,3 мг/кг соответственно).

Содержание подвижных форм К, Fe и $\mathrm{Sr}$ закономерно снижается вниз по почвенному разрезу. В случае с K и Sr такое распределение может быть связано с активным накапливанием микроэлементов в наземной фитомассе [Шеуджен, 2003]. Концентрации Al и $\mathrm{Pb}$, напротив, закономерно увеличиваются с глубиной.

Склон юго-восточной экспозиции (точка 3) имеет наиболее активный промывной режим на территории, принимает поверхностный сток с водораздельного участка, а также характеризуется более интенсивным, глубинным промачиванием поверхности. Почва, сформированная на данном склоне, - дерново-бескарбонатная супесчано-суглинистая скелетная, сложенная на делювии верхнеюрских туфов и туфобрекчий. Почва развивается в трансаккумулятивных условиях под пушистодубовым лесом. Поверхность склона имеет уклон $15^{\circ}$ в сторону моря.

Здесь отмечено следующее распределение химических элементов по почвенному разрезу: валовые формы $\mathrm{K}, \mathrm{Mg}, \mathrm{Fe}, \mathrm{Mn}, \mathrm{Zn}$ и $\mathrm{Pb}$, наряду с подвижными формами этих элементов, аккумулируются в верхних горизонтах. Пределы изменения, по сравнению с нижележащими горизонтами, следующие: K (от 170 до 941,1 мг/кг), Zn (от 0,4 до 1,8 мг/кг) и Сu (от 0,1 до 0,3 мг/кг), что говорит об активном участии данных элементов в росте и развитии растений. Обратное поведение в распределении подвижных форм элементов имеют $\mathrm{Mg}, \mathrm{Al}$ и $\mathrm{Fe}$, 
содержание которых увеличивается в минеральных горизонтах. Данное обстоятельство может, с одной стороны, свидетельствовать о высоком содержании этих элементов в почвообразующих горных породах, а с другой - об их активной миграции из верхних горизонтов вследствие достаточного увлажнения. Необходимо также отметить значительные концентрации в почвах $\mathrm{Fe}$ и $\mathrm{Al}(9763,7-17434$ мг/кг для $\mathrm{Al}$ и 3258,6-7019,3 мг/кг для Fe) в валовой форме на фоне низких концентраций их подвижных форм (от 11-19,2 мг/кг для Al и 14,2-19,3 мг/кг для Fe). Это указывает на то, что $\mathrm{Al}$ и $\mathrm{Fe}$ в почве образуют малорастворимые комплексы (например, вследствие коагуляции Fе с гумусовыми кислотами).

Особое внимание необходимо уделить распределению валовых форм таких элементов, как $\mathrm{Al}$ и $\mathrm{Cu}$, накапливающихся в горизонте А. Этот процесс может быть связан с проявлением механического барьера в указанном горизонте, что видно из данных гранулометрического состава происходит резкое увеличение количества глинистой фракции < 0,1 мм до 25,6 \% в сравнении с другими горизонтами. Таким образом, сами по себе алюмосиликаты накапливаются в этом горизонте в виде малорастворимых комплексов.

Важно отметить влияние моря на склон юго-восточной экспозиции. Такие условия способствуют накапливанию некоторых элементов, забрасываемых с морскими аэрозолями в верхние горизонты почвы. Это видно по характеру распределения $\mathrm{Sr}$ по почвенному разрезу. Sr накапливается в верхнем органическом горизонте, достигая максимума концентрации как в валовой (60,7 мг/кг), так и в подвижной форме (22,1 мг/кг). Высокое содержание подвижной формы Mn в верхних горизонтах (Ad и A) может быть связано с содержанием органических гумусовых веществ.

\section{Выводы}

Bсе рассматриваемые нами почвенные разрезы заложены в пределах одной геологической формации вулканического происхождения, представленной породами туфов и туфобрекчий, потоками спилитов, кератоспилитов, андезитов и андезито-базальтов верхнебайоского возраста. Геологическая обстановка территории обеспечивает содержание большого количества таких элементов, как $\mathrm{Mg}, \mathrm{Al}$ и $\mathrm{Fe}$. Делювий горных пород активно перемещается по склонам и накапливается, являясь источником химических элементов, вовлечённых в почвообразовательный процесс.

Отмечается миграция элементов из почв, формирующихся в автоморфных условиях на водораздельном участке хребта Магнитного (точка 2), и их накапливание в почвах соподчинённых лесных ландшафтов на склонах (точки 1 и 3). Это характерно для всех рассматриваемых элементов. Происходит частичная аккумуляция валовых форм исследуемых элементов и последующий их смыв на прилегающие склоны (точки 1 и 3) посредством поверхностного стока. Концентрация всех рассматриваемых элементов (K, Mg, Al, Fe, Mn, $\mathrm{Sr}, \mathrm{Zn}, \mathrm{Cu}, \mathrm{Pb}$ ) в верхних горизонтах почвы выше на склонах, которые связаны с трансаккумулятивными условиями развития почв, чем на водораздельной поверхности, находящейся в автоморфных условиях развития почвы.

Благодарности. Работа поддержана Программой стратегического академического лидерства РУДН. 


\section{Список литературы}

1. Алексашкин И. В., Хижняк Ю. С., Горбунов Р. В. Факторы и общие закономерности поведения тяжёлых металлов в почвах // Записки общества геоэкологов. - 2007. - Вып. 9. - С. 17-23.

2. Алексеенко В. А., Бузмаков С. А., Панин М. С. Геохимия окружающей среды : учеб. пособие для вузов. - Пермь : Перм. гос. нац. исслед. ун-т, 2013. - 359 с.

3. Важкі метали у грунтах заповідних зон України / НАН України, Ін-т геохімії, мінералогії та рудоутворення ; голов. ред. Е. Я. Жовинський. - Київ : Логос, 2005. - 104 с.

4. Ежов А. Ю., Лебедев Я. О., Горбунов Р. В., Хижняк Ю. С., Горбунова Т. Ю., Кошовская О. С., Ревина Я. С., Ключкина А. А. Особенности влияния антропогенных загрязнений и приморского положения территорий на процессы почвообразования // Исследования в области естественных наук. - 2014. - № 11. - C. 31-35. - URL: https://science.snauka.ru/2014/11/8668 (дата обращения: 25.08.2021).

5. Жовинский Э. Я., Кураева И. В. Геохимия тяжёлых металлов в почвах Украины. - Киев : Наук. думка, 2002. - $213 \mathrm{c}$.

6. Иванов B. Н. Почвы Крыма и повышение их плодородия. - Симферополь : Крымиздат, 1958. $-184 \mathrm{c}$.

7. Кочкин М. А. Почвы, леса и климат горного Крыма и пути их рационального использования. Москва : Колос, 1967. - 368 с.

8. Локтионова Е. П., Кураева И. В., Войтюк Ю. Ю., Матвиенко А. В. Литолого-геохимические особенности поверхностных отложений и закономерности отложения микроэлементов в природных объектах восточной части Южного берега Крыма // Экосистемы, их оптимизация и охрана. - 2014. - № 11. - С. 93-98.

9. Михаленок Д. К. Ландшафтно-геохимические особенности Восточной части горного Крыма : автореф. дис. ... канд. геогр. наук : 11.00.01. - Москва, 1989. - 16 с.

10. Опанасенко Н. Е. Скелетные почвы Крыма и плодовые культуры. - Херсон : Савченко А. В., 2014. - $333 \mathrm{c}$.

11. Петрографическая карта Карадага, 1925-1926 гг. // Вулканическая группа Карадага в Крыму / Ф. Ю. Левинсон-Лессинг, Е. Н. Дьяконова-Савельева. - Ленинград : Изд-во Акад. наук СССР, 1933. - [Прил.].

12. Шеуджен А. Х. Биогеохимия. - Майкоп : Адыгея, 2003. - 1028 с.

\section{DISTRIBUTION AND MIGRATION OF CHEMICAL ELEMENTS IN SOILS OF THE MAGNITNYJ RIDGE (KARADAG NATURE RESERVE)}

\section{Drygval P. V. ${ }^{1}$, Drygval A. V. ${ }^{2}$, Lebedev Ya. O. ${ }^{3}$, Gorbunov R. V. ${ }^{2}$, Stanis E. V. ${ }^{1}$,} Pham Cam Nhung ${ }^{2}$

${ }^{1}$ Peoples' Friendship University of Russia (RUDN University), Moscow, Russian Federation,

${ }^{2}$ A. O. Kovalevsky Institute of Biology of the Southern Seas of RAS, Sevastopol, Russian Federation,

${ }^{3}$ Moscow representative office A. O. Kovalevsky Institute of Biology of the Southern Seas of RAS, Moscow, Russian Federation,

e-mail: any-poly@mail.ru

The article considers the distribution and migration of some chemical elements within the soil catena, that laid in the territory of the Karadag mountain group. The catena is represented by three points (soil profile cuts), which laid on the top of the ridge Magnitnyj, as well as on its slopes north-west and south-east exposures. The soil profile cuts are laid in automorphic and trans-accumulative conditions of soil formation. Descriptions of each soil profile cut are given, and chemical analysis of soil samples of each horizon is carried out. The actual acidity, the amount of humus, the content of some micro- and macroelements in total and active forms have been determined for the soil samples. The nature of distribution and migration of some chemical elements within the soil 
profile cuts and soil catena in general is considered. In the article it is noted that there is a migration of the studied elements from soils formed in automorphic conditions on watershed area of ridge Magnitnyj (soil profile cut № 2) and their accumulation in the co-located forest landscapes on the slopes (soil profile cuts № 1 and № 3). It is revealed that the concentration of all studied elements in the upper soil horizons is higher on slopes, which are associated with trans-accumulative conditions of soil formation, than on the watershed surface, associated with automorphic conditions of soil formation.

Keywords: migration of elements, soils of nature reserve, geochemical co-ordination, soil catena, Karadag nature reserve

\section{Сведения об авторах}

\begin{tabular}{|c|c|}
\hline $\begin{array}{l}\text { Дрыгваль } \\
\text { Полина } \\
\text { Валерьевна }\end{array}$ & $\begin{array}{l}\text { acпирант, ассистент, Российский университет дружбы } \\
\text { any-poly@mail.ru }\end{array}$ \\
\hline $\begin{array}{l}\text { Дрыгваль } \\
\text { Анна } \\
\text { Валерьевна }\end{array}$ & $\begin{array}{l}\text { младший научный сотрудник, ФГБУН ФИЦ «Институт биологии южных морей } \\
\text { имени А. О. Ковалевского РАН», drygval@ mail.ru }\end{array}$ \\
\hline $\begin{array}{l}\text { Лебедев } \\
\text { Ярослав } \\
\text { Олегович }\end{array}$ & 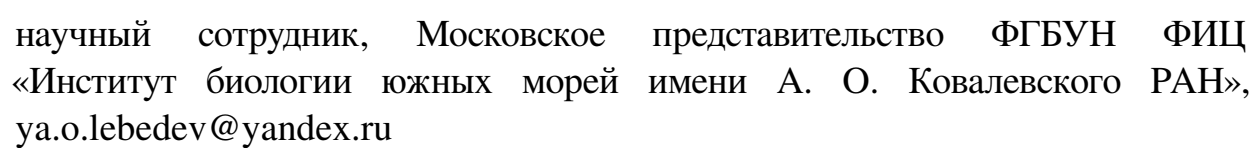 \\
\hline $\begin{array}{l}\text { Горбунов } \\
\text { Роман } \\
\text { Вячеславович }\end{array}$ & $\begin{array}{l}\text { кандидат географических наук, директор, ФГБУН ФИЦ «Институт биологии } \\
\text { южных морей имени А. О. Ковалевского РАН», karadag_station@ @ail.ru }\end{array}$ \\
\hline $\begin{array}{l}\text { Станис } \\
\text { Елена } \\
\text { Владимировна }\end{array}$ & $\begin{array}{l}\text { кандидат технических наук, профессор, Российский университет дружбы на- } \\
\text { родов, estanis@ @ail.ru }\end{array}$ \\
\hline Фам Кам Ньунг & $\begin{array}{l}\text { кандидат химических наук, младший научный сотрудник, ФГБУН ФИЦ } \\
\text { «Институт биологии южных морей имени А. О. Ковалевского РАН», } \\
\text { nhung5782@yahoo.com }\end{array}$ \\
\hline
\end{tabular}

Поступила в редакцию 28.09.2021 2. Принята к публикации 25.10.2021 2. 